\title{
Contribution of wetland resources to household food security in Uganda
}

Nelson Turyahabwe ${ }^{1 *}$, Willy Kakuru², Mnason Tweheyo ${ }^{2}$ and David Mwesigye Tumusiime ${ }^{3,4}$

\begin{abstract}
Background: In Uganda, nearly 1.4 million people are currently food insecure, with the prevalence of food energy deficiency at the country level standing at 37\%. Local farmers are vulnerable to starvation in times of environmental stress, drought and floods because of dependence on rain-fed agriculture. Accordingly, the farmer's means of increasing food production has always been an expansion of area under cultivation from virgin and fragile areas, especially wetlands. Consequently, Uganda has lost about $11,268 \mathrm{~km}^{2}$ of wetland, representing a loss of $30 \%$ of the country's wetlands from 1994 to 2009. While the environmental importance of wetland ecosystems is widely recognized, their contribution to household food security is still hardly explored. In this paper an assessment of the contribution of wetland resources to household food security and factors influencing use of wetland resources in Uganda are reported.
\end{abstract}

Methods: A number of livelihood tools in food security assessment including focus group discussions, key informant interviews, direct observations and a household questionnaire survey, were used to collect the data. A total of 247 respondents from areas adjacent to wetlands were involved in the household questionnaire survey conducted in three agro-ecological zones that are frequently characterized as food insecure.

Results: The findings indicate that about $83 \%$ of the households experienced food insecurity. The main indicators of food insecurity were low harvest (30.9\%) and when people buy locally grown food items (18\%). Most households felt food secure when they had perennial crops (43.2\%) in their gardens, or adequate money to buy food (23.9\%). The prevalence of food insecurity was significantly lower among households with older and better educated household heads, but also among households located in Lake Victoria Crescent and South western farmlands agroecological zones, but significantly higher among households that were female headed, larger and participate in collection of wetland resources. Over $80 \%$ of the respondents reported that wetland resources provide products and services that contribute enormously to their household food security. Besides, they also indirectly contribute to food security by providing services that foster food production such as weather modifications and nutrient retention. Households with older heads and those that reside in the Lake Victoria Crescent agro-ecological zone when compared to counterparts in the Lake Kyoga agro-ecological zone are more likely to have a higher dependence on wetlands for food security.

Conclusions: With increasing population around the wetlands, coupled with land shortage and weather variations, households with limited options will continue to generally rely on wetlands for food security and income for sustaining their livelihoods unless alternative livelihood options are provided. There is thus a need to design appropriate food production technologies that ensure sustainable use of wetland resources for food security.

Keywords: Food security, Food insecurity, Wetland management, Wetland resources, Uganda

\footnotetext{
* Correspondence: turyahabwe@forest.mak.ac.ug

${ }^{1}$ Department of Extension and Innovation Studies, College of Agricultural and Environmental Sciences, Makerere University, P.O. Box 7062, Kampala, Uganda

Full list of author information is available at the end of the article
}

\section{Biomed Central}

(c) 2013 Turyahabwe et al.; licensee BioMed Central Ltd. This is an Open Access article distributed under the terms of the Creative Commons Attribution License (http://creativecommons.org/licenses/by/2.0), which permits unrestricted use, distribution, and reproduction in any medium, provided the original work is properly cited. 


\section{Introduction}

Food is the basic human need for survival, health and productivity. It is the foundation for human and economic development [1]. In a broad sense, food security exists when "all people, at all times, have physical, social and economic access to sufficient, safe and nutritious food that meets their dietary needs and food preferences to live an active and healthy life" [2]. On the other hand, food insecurity occurs when food systems are stressed such that food is not available, accessible or utilized properly.

Most households especially in developing nations are food insecure partly due to the rapid increase in human population, weather and climatic variability, and environmental degradation. For instance in 2009, it was estimated that 102 billion people were undernourished worldwide, which is about $37 \%$ higher than 20 years ago [3]. SubSaharan Africa and South Asia are the regions most affected by food insecurity, being home to $60 \%$ of the world's food insecure people. In the case of sub-Saharan Africa, the food situation is further aggravated by low per capita food availability, high fluctuations in food supply and lack of innovative ideas as well as responsive policies for sustainable use and management of natural resources. In sub-Saharan Africa, the predominance of rain-fed agriculture often results in food systems that are highly sensitive to rainfall variability $[4,5]$. The region thus remains susceptible to frequent food crises and famines. Sub-Saharan Africa is the only region of the world where hunger is projected to worsen over the next two decades unless drastic measures are taken to improve governance of its natural resources and achieve the economic development required to reverse the current trend [6].

Over, the past decades, there has been an increasing influx of people into wetland areas as a coping strategy, especially in areas where uplands are predominantly characterized by low agricultural potential, dominated by poor soils and low unpredictable rainfall [7-11]. This is further due to the presence of water in wetlands during the dry season, combined with their natural fertility and irrigation potential [12-14]. Wetlands are also used to secure food not only directly through dry season subsistence cultivation but also indirectly through income generation from cash crops, the production of clay for pottery, reed and palm mats, baskets and beehives, and the sale of collected items, thus acting as safety nets for most adjacent communities [15-18]. In the drier regions, wetlands are the only sites where people can get water, varieties of food and other basic supplies [19-21].

The National Development Plan (NDP) indicated that the food security situation in Uganda has been unsatisfactory [22]. Nearly 1.4 million people are currently food insecure despite the country's abundant resources [23], with the prevalence of food energy deficiency at the country level standing at 37\% [1]. According to a report by the World
Food Programme (WFP) [24], about 6.1 million (21\%) people in Uganda are undernourished. The report further identifies that at the household level, about $6.3 \%$ of the households in Uganda are food insecure and that food insecurity is most common among the natural resources dependant households. About $86 \%$ of Uganda's population live in rural areas and are predominantly rural farmers and agricultural practice is predominantly rain-fed, characterized by low levels of crop productivity. The people are generally cash-poor, with over $40 \%$ living below the poverty line, on less than a dollar a day. Most of these people are perennially food insecure and are thus vulnerable to starvation in times of environmental stress, drought and floods [25].

Accordingly, the farmer's means of increasing agricultural output has always been an expansion of area under cultivation. Additional land is often brought under agriculture either through reduction in fallow periods or cultivation of virgin areas, especially forests and wetlands $[25,26]$. As noted by Nyakana [27], and Mwakubo and Obare [21], an increasing number of marginalized people are moving into fragile wetland areas, in search of new means of livelihood, including crop farming, fishing and livestock grazing. Crops commonly grown on the wetland periphery include: Dioscorea spp (yams), beans, Zea mays (maize), Ipomoea batatas (L.) Lam. (sweet potatoes), Manihot esculenta Crantz (cassava), Brassica oleracea var. capitata (cabbages), Saccharum officinale (sugar cane) and low land rice [28]. Consequently, Uganda has lost about 11,268 km² of wetland, down from $37,575 \mathrm{~km}^{2}$ (15.6\%) in 1994 to about $26,308 \mathrm{~km}^{2}(10.9 \%)$ in 2009 . This represents a loss of $30 \%$ of the country's wetlands [28]. To date, this loss is expected to be even higher.

Despite their contribution to rural livelihoods, wetland resources have been overlooked in national economic development planning. Thus, the current development pathways will continue to underestimate the significance of these resources, and in so doing, miss opportunities for reducing food insecurity and sustainable management of wetland systems. While the environmental importance of wetland ecosystems is widely recognized, the potential contribution of wetland resources to household food security is still hardly explored. Understanding the degree to which wetlands contribute to people's food security may be vital in steering decisions that minimize negative impacts or enhance the benefits that wetlands have for communities. As such, this study endeavored to provide this information. Such information is fundamental in developing interventions for sustainable wetland management in order to achieve the National Food Security targets and the Millennium Development Goal (MDG) 1 of halving the proportion of people who suffer from hunger by 2015, and MDG 7 on environmental sustainability. The objectives of this study were thus threefold, namely to: i) map 
the experiences and perceptions of the local people on the food security situation; ii) assess the contribution of wetlands to food security; and iii) determine factors that influence dependence on wetlands for food production in Uganda.

\section{Methods}

\section{Study area}

Out of the ten Ugandan agro-ecological zones, three were randomly selected (Lake Victoria Crescent, Kyoga plains and South western farmlands) (Figure 1). A National Wetland Inventory of 1999 [29] identifies four key factors by which to categories wetlands. These include agroecological factors of the wetland system and the level of food security, population density and farming systems of the local communities in proximity to the wetland system. Based on these characteristics, wetlands in each of the three zones were categorized into strata. Random selection was used to sample Munyere and Mabamba Bay wetlands in Wakiso district to represent the Lake Victoria Crescent agro-ecological zone. This zone is characterized by medium level of food security, and a high population density of 484 persons per $\mathrm{km}^{2}$. Lake Opeta in Pallisa district and Limoto wetland in Kibuku district represented Kyoga

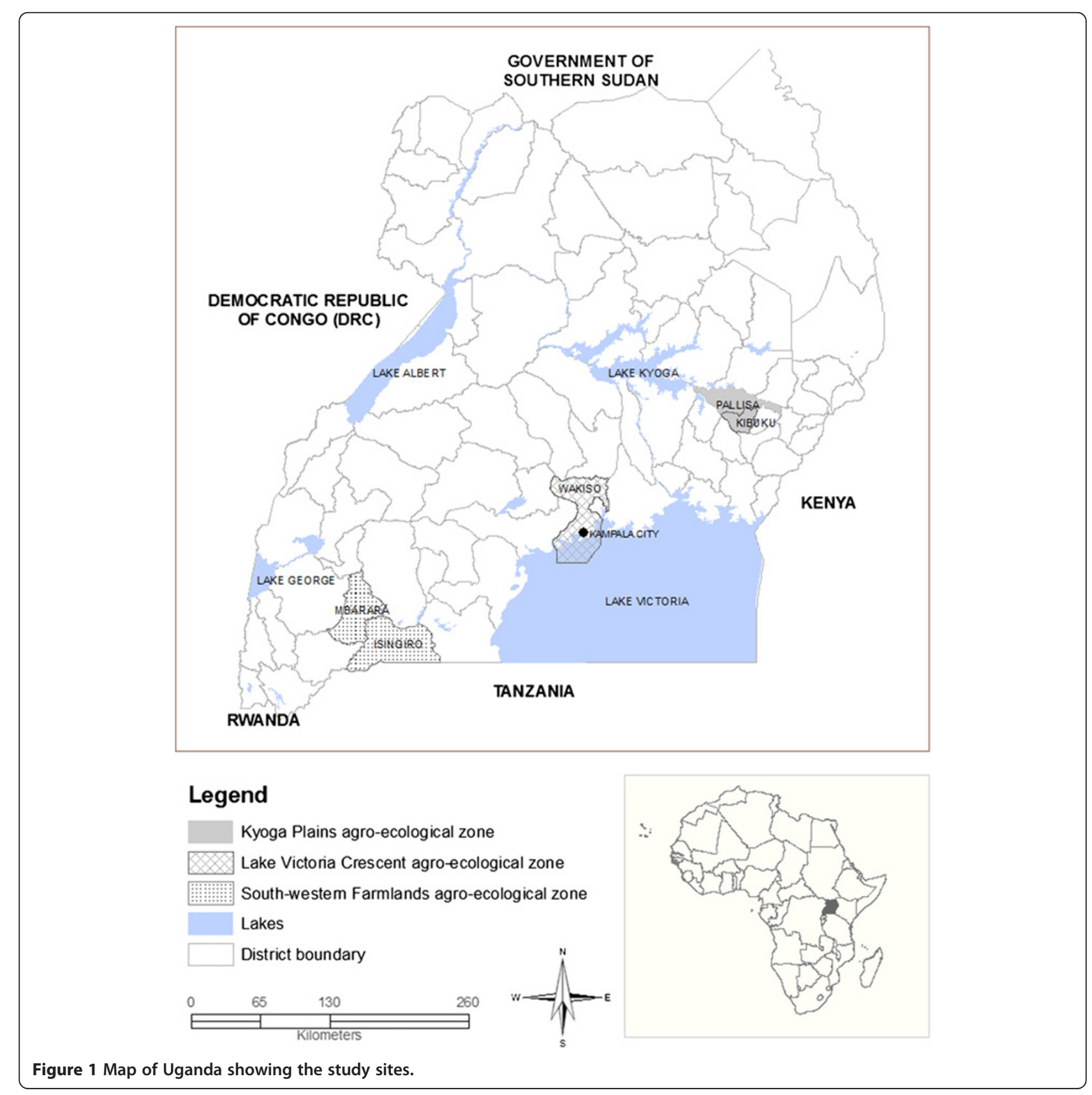


plains agro-ecological zone characterized by small-scale subsistence, mainly annual crops with some pastoralism and with a high level of food insecurity and a moderate population of 252 persons per $\mathrm{km}^{2}$. While Lake Nakivale in Isingiro district and Rucece in Mbarara district represented the south-western farmlands agro-ecological zone with moderate level of food security and a moderate population density of about 247 persons per $\mathrm{km}^{2}$. The three zones represent three regions in Uganda which are often regarded as food insecure [24].

\section{Data collection}

We employed data collection methods and tools for assessing food security following Lisa et al. [1] and Young et al. [30], by taking a qualitative measure to capture people's own perceptions of the extent to which they suffer from food shortage [31] and their understanding of the causes of food insecurity; and information on what resources local people directly and indirectly obtain from wetlands for food security. Semi-structured interviews were administered to two hundred and forty seven (247) households randomly selected from $5 \mathrm{~km}$ of the wetland edges (i.e., 82 from south-western farmlands agro-ecological zone, 81 from Lake Victoria Crescent and 84 from Kyoga plains). We targeted household heads as our interviewees, but in a few instances where the heads were absent, selected the most senior and knowledgeable of the adults present. We carried out the interviews in the common local language. Before conducting each individual interview, it was made clear that the purpose of the study was purely scientific and academic. It was emphasized that the study had no legal implications whatsoever, and the respondents were also assured of confidentiality and anonymity.

The questionnaire was pre-tested in one village that was not part of the selected sample. Pre-testing allowed the interviewers to gain familiarity with the questionnaire and provided an opportunity to apply and review the method. The focus was on assessing how respondents understood our questions and identifying any problems encountered in providing answers. Changes were proposed, reviewed and incorporated into our final questionnaire. The questionnaire focused on respondents' understanding of food security/insecurity issues, main wetland products harvested for consumption or sale and other activities undertaken that directly or indirectly contribute to household food security.

Further, one focus group discussion (FGD) was conducted in each sample parish to generate information on key wetland resources used by surrounding communities. Particular attention was given to women due to their key role in household food security [28]. Key informant interviews were held with staff from National Environmental Management Authority (NEMA), Wetlands Management Department, Wetland and Production units of the Respective District and sub-county Local Governments, Natural
Resources Committees at the Districts, production and environmental Committees, National Agricultural Advisory Services (NAADS), and representatives of different wetland user groups to ascertain: the kind of wetland resources directly harvested for food security, the status of food security/insecurity in the areas and means of deriving livelihoods. Also, direct field observations were made on activities undertaken in the sample wetlands.

\section{Data analysis}

Questionnaire responses were edited, coded and analyzed using SPSS version 18.0 for Windows. Spatial differences were captured through the construction of three dummy variables based on location of the sample household in one of the three agro-ecological zones. In all cases, a dummy variable was coded 1 for a household located in that agroecological zone and 0 otherwise. Frequencies were generated to capture local experiences and perceptions of the food security situation. A binary variable depicting whether or not a household had experienced food insecurity in the last five years was regressed against household socioeconomic factors to determine factors that influence susceptibility to food insecurity [32]. The contribution of wetlands to food security was ascertained by examining the frequencies of the wetland products harvested for food security. Binary variables depicting whether or not a household i) had experienced food insecurity, and ii) depended on wetland resources for food security, were regressed against household socioeconomic factors to determine the latter's influence over these two outcomes. Marginal effects of each of these variables were examined using Stata Margeff program [33]. All categorical variables were specified as dummies using the dummies option and the agro-ecological zones were specified as dummies with Kyoga plains as the base. Following Wooldridge's [34] suggestion, for location dummies, we report exact percentage differences in the predicted dependent variable when a household is resident in either zone compared to Kyoga plains. The percentage difference is computed as $100\left[\mathrm{e}^{(\beta \wedge)}-1\right]$, where ${ }^{\beta^{\wedge}}$, is the coefficient on the respective dummy variable; $\chi^{2}$ tests were used to examine the existence of associations between the contribution of wetlands to food security and age, landholding, occupation, household size, gender and education level of the respondent. All statistical tests were performed at $5 \%$ significance level.

\section{Results}

\section{Household characteristics}

The majority of respondents (65\%) were males, with an average age of 40 years. Most respondents (90\%) had formal education. The main occupation of respondents was farming. The other sources of income included tailoring, petty trade, brick making, fishing and working as drivers, tourist guides, mechanics, builders and causal laborers. 
The average household size was eight persons with some households having up to 21 members. On average, most respondents had stayed in the area for at least 24 years, and within a distance of $5 \mathrm{~km}$ to the wetland edge. Most respondents earned less than UGX 100,000 (approx. USD 40) per month with average monthly income of UGX 97,000 (approx. USD 39) indicating that they were generally poor. Most of the respondents owned less than five acres of land with average land owned at 3.8 acres, indicating a low per capita land holding.

\section{Local experiences and perception of food security situation}

Over $80 \%$ of the households reported experiences of food insecurity during the past five years and attribute it to different causes. The most frequently mentioned cause was climate change. Included in this category is the explicit mention of climate change (50\%), mentions of the related causes: prolonged drought (42\%) as in the quote below, floods $(2 \%)$, and reduction in quantity of water in wetland (1\%). Other relatively pervasive causes included limited access to land, labor and the sale of food crops to raise cash income (Figure 2).

In my opinion, the single most important cause of food insecurity in our villages are prolonged droughts which do not only scorch our crops in the fields, but also limit our abilities to plant new crops. Droughts affect crop and livestock farmers alike (Participant in a focus group discussion in Isingiro District).

A number of factors are perceived as indicators of food insecurity, but main ones are situations of low household food harvest and when people buy locally grown food items (Figure 3).

However, prevalence of food insecurity is significantly lower among households with older and better educated household heads. However, the marginal effect of age is low (Table 1). Keeping other things equal, the likelihood of being food insecure reduces by only $0.3 \%$ for an additional year in age of household head. Education has a greater effect, and the likelihood of household experiencing food insecurity reduces by about $12 \%$ for every extra year its head spent in school. In terms of location, keeping other things equal, the difference in likelihood of experiencing food insecurity reduces by nearly $17 \%\left(100\left[\mathrm{e}^{(0.155)}-1\right]\right)$ if a household is resident in south western farmlands as compared to Kyoga plains, and about $14 \%\left(100\left[\mathrm{e}^{(0.130)}-1\right]\right)$ if resident in Lake Victoria Crescent.

On the other hand, keeping other variables equal, the likelihood of experiencing food insecurity increases by $13 \%$ if a household is female headed, by $1.3 \%$ for each extra member to a household, and $23 \%$ if a household participates in collection of wetland products for food security.

\section{Contribution of wetlands to household food security}

Wetlands were reported to contribute to household food security through provision of wetland products and services.

\section{Wetland products}

Over $75 \%$ of the respondents acknowledged that wetlands directly contribute to their household food security. They do so in a number of ways, but the most pervasive are three; direct consumption of wetland products, wetlands providing space for growing crops, and the sale of wetland products to raise cash income that is then used to purchase food (Figure 4). As one farmer noted in a focus group discussion in the Kyoga plains "wetlands are the lifeline of many a local farmer who feed on and sometimes sell wetland products".

\section{Direct consumption of wetland products}

Wetlands are reported to be a source of a variety of resources that are directly consumed among $86 \%$ of the sample households (Figure 4). Water was identified by up to $60 \%$ of the sample households as the most important product directly obtained for domestic and livestock use.

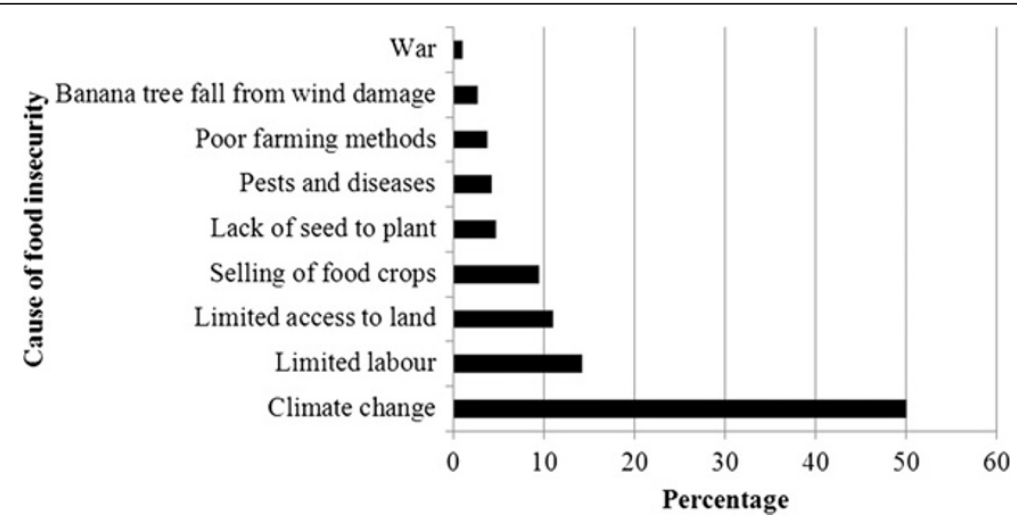

Figure 2 Frequency of mention of the different causes of food insecurity among households adjacent to wetlands in Uganda. 


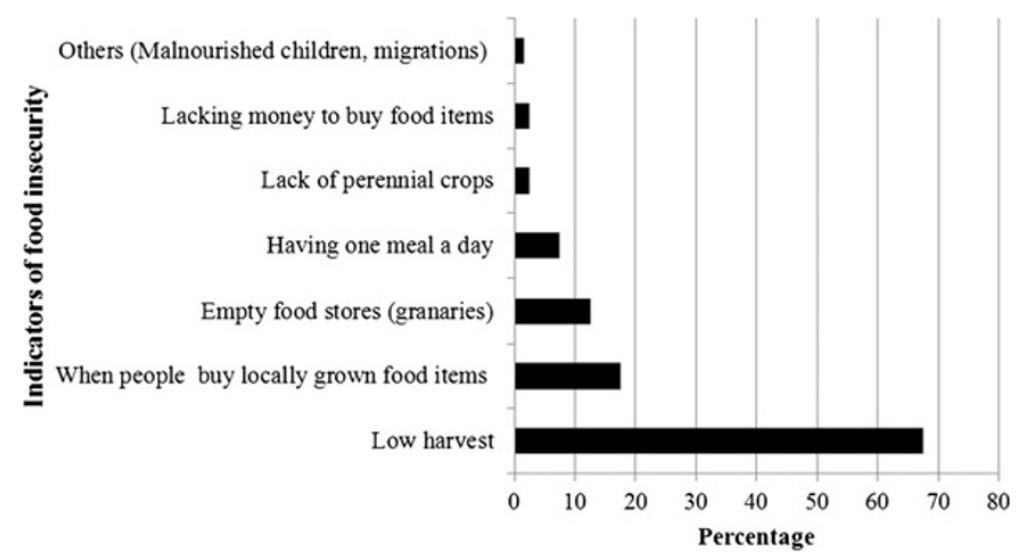

Figure 3 Perceived indicators of food insecurity among households adjacent to Wetlands in Uganda.

Other important products included fish and bush meat (mainly Sitatunga and wild rat). The main indigenous fruits harvested from wetlands were Afromomum spp (A. angustfolium, and A.mildbraedi) and Physalis micrantha (Entutu), while main vegetables included Amaranthus spp (dodo) and Solanum nigrum (Eswiga).

There was a significant association between collection of wetland products for direct home use and the income level of the respondents $\left(\chi^{2}=6.858, \mathrm{df}=3, P=0.001\right)$. Generally, respondents earning less than UGX 100,000 (approx. USD
40) per month were more likely to collect products for direct home use. Other noticeable variations included variation in harvesting of fish with gender, age and household size. Fish collection is closely associated with males $\left(\chi^{2}=\right.$ $5.755, \mathrm{df}=1, P=0.016)$, younger individuals $(<45$ years $)$ $\left(X^{2}=5.307, \mathrm{df}=2, P=0.042\right)$, and members of larger households ( $>7$ members) $\left(X^{2}=24.984, \mathrm{df}=2, P=0.000\right)$. The latter were also more associated with collection of fruits and vegetables $(14.1 \%)\left(\chi^{2}=6.901, \mathrm{df}=2, P=0.032\right)$, papyrus materials $\left(X^{2}=10.405\right.$, df $\left.=2, P=0.006\right)$, and

Table 1 Household characteristics that influence susceptibility to food insecurity among households adjacent to wetlands in Uganda

\begin{tabular}{|c|c|c|c|c|c|}
\hline Dependent variable* & Units & Coef. & Std. Err. & $\mathbf{z}$ & $P>z$ \\
\hline \multicolumn{6}{|l|}{ Household characteristics } \\
\hline Age & Years & -0.003 & 0.002 & -1.80 & 0.071 \\
\hline Household female headed & $0 / 1$ & 0.129 & 0.045 & 2.85 & 0.004 \\
\hline Education level & Years & -0.117 & 0.028 & -4.14 & 0.000 \\
\hline Household size & Number & 0.013 & 0.006 & 2.09 & 0.037 \\
\hline Length of stay in the area & Years & 0.001 & 0.001 & 0.66 & 0.508 \\
\hline Distance to wetland & $\mathrm{km}$ & 0.061 & 0.043 & 1.40 & 0.160 \\
\hline Location in south-western farmlands & $0 / 1$ & -0.155 & 0.083 & -1.87 & 0.062 \\
\hline Location in Lake Victoria Crescent & $0 / 1$ & -0.130 & 0.078 & -1.66 & 0.097 \\
\hline Primary occupation is farming & $0 / 1$ & -0.029 & 0.068 & -0.43 & 0.669 \\
\hline Primary occupation is formal employment & $0 / 1$ & 0.038 & 0.105 & 0.36 & 0.719 \\
\hline Household collects wetland products & $0 / 1$ & 0.229 & 0.117 & 1.97 & 0.049 \\
\hline Number of observations & & & & & 236 \\
\hline Log likelihood & & & & & -83.1 \\
\hline $\operatorname{LR} x^{2}(11)$ & & & & & 42.04 \\
\hline Prob $>x^{2}$ & & & & & 0.000 \\
\hline Pseudo R2 & & & & & 0.202 \\
\hline
\end{tabular}

*Dependent variable is a binary variable depicting whether or not a household had experienced food insecurity $(1=$ Household had experienced food insecurity in the last five years; $0=$ Otherwise). 


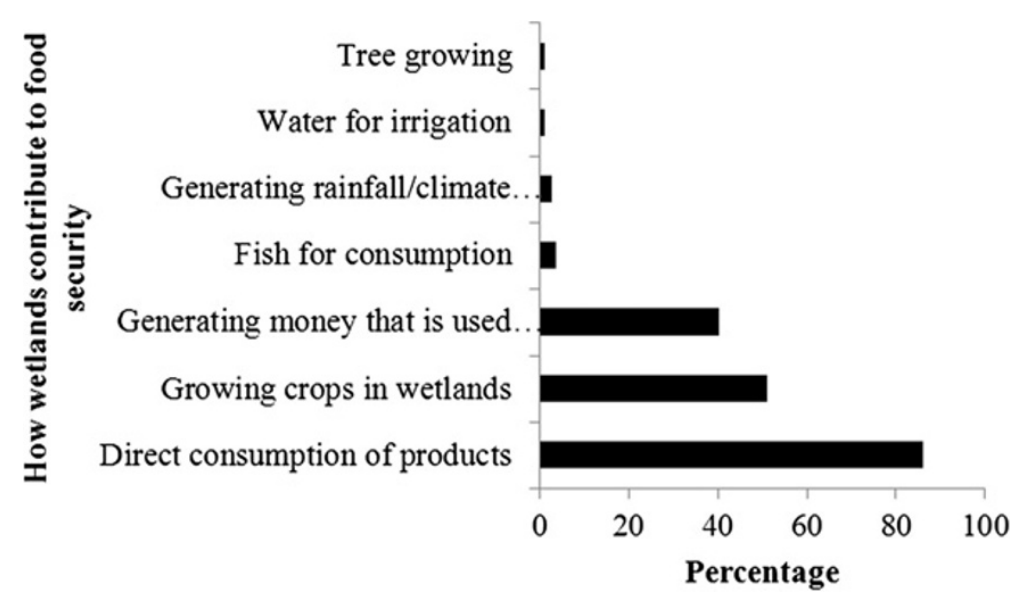

Figure 4 Ways through which wetlands contribute directly to household food security in areas adjacent to wetlands in Uganda.

medicinal herbs $\left(x^{2}=11.760, \mathrm{df}=2, P=0.003\right)$. The herbs particularly played an important role in maintaining the health of local people.

\section{Growing of crops in wetlands}

Wetlands also contributed to food security through providing space for growing crops, and the sale of wetland products to raise cash income that is then used to purchase food (Figure 4). The main crops grown by respondents in wetlands were vegetables, sugarcane, coco yams and paddy rice. Paddy rice was the main crop grown in Kyoga plains, and vegetables in south-western farmlands and Lake Victoria Crescent. Vegetable production was common to all wetlands. The main vegetables grown were Amaranthus dubius (Dodo), Amaranthus lividus (A. blitum) Ebugga, Solanum aethiopicum (Nakati), Brassica olerace (cabbages), tomatoes (Solanum lycopersicum), Solanum melongena L. (egg plants), pumpkins (Cucurbita maxima Lam.), watermelons Citrullus lanatus (Thunb.) Matsum and Entura (Solanum aethiopicum gilo.). The other crops grown were maize, sweet potatoes, fruits, ground nuts and cotton. There are observable significant differences in the extent of use of wetlands for growing crops across the agroecological zones $\left(X^{2}=33.34, \mathrm{df}=2, \quad P=0.000\right)$. The practice is widespread in Kyoga plains where households report to derive about half of the household food from the wetlands particularly through cultivation of paddy rice, and an average household derives more than half of its cash income from the sale of crops grown in the wetlands.

\section{Sale of wetland products for cash}

Wetlands also indirectly contributed to food security through provision of resources sold for cash that was used to buy food. About $60 \%$ of the respondents harvested and sold wetland resources for cash to purchase food. Of these, about $38.4 \%$ spent one quarter of the income generated from sale of wetland products to buy food, $28.5 \%$ one quarter to half, $20.1 \%$ spent a half to three quarters and $12.9 \%$ three quarters. Main food items bought with such cash were mainly food security crops such as millet, maize flour and cassava.

There was a wide variation across agro-ecological zones in participation in these sales. Highest records are in the south-western farmlands where up to $86 \%$ of the households participate as compared to $46 \%$ and $38 \%$ in Kyoga plains and Lake Victoria Crescent, respectively. The main items sold were fish, fruit and vegetables, papyrus, medicinal herbs and craft materials, and these jointly generated a monthly income of UGX 99,208 (approx. USD 36) to an average household. However, the income accruing to an average household differed significantly between the agroecological zones ( $\mathrm{F}=3.89, \mathrm{df}=2, P=0.022$ ). Households in Kyoga plains obtained a significantly higher amount of cash from such sales (Figure 5). Fish was generally ranked as the most frequently sold resource, followed by poles which were either sold for cash or processed into different items such as hoe handles, and mortars and pestles for local processing of food.

There was an association between dependence on sales of wetland products for purchasing household food and income level $\left(\mathrm{X}^{2}=21.742, \mathrm{df}=3, P=0.000\right)$, proximity to the wetland $\left(X^{2}=7.291, \mathrm{df}=1, P=0.000\right)$ and size of land owned $\left(X^{2}=9.508, \mathrm{df}=1, P=0.000\right)$. The practice was most frequent among households with monthly income less than UGX 200,000 (approx. USD 80.), living within a distance of less than $<1 \mathrm{~km}$ of the wetland edge, and owning less than one acre of land.

\section{Wetland services}

Wetlands provided services to local people that enhanced their livelihoods in meeting their food security requirements. The most pervasive of these services include weather modification, cleaning water before local use, acting 


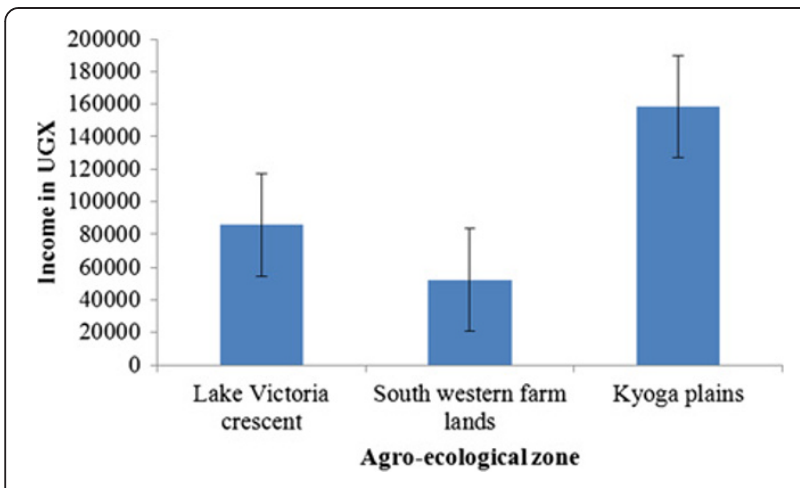

Figure 5 Monthly cash income from sale of wetlands products in three agro-ecological zones of Uganda.

as breeding grounds for fish, and provision of water transport and tourism (Figure 6).

Factors that influence dependence on wetlands for food production

There is a wide variation in dependence on wetlands for food security (Table 2). Keeping other things equal, seniority in age of the household head increases dependence on wetlands for food security, although only marginally. For every additional year the likelihood increases by $0.3 \%$. On the other hand, residence in the Lake Victoria Crescent increases this likelihood by about $6 \%\left(100\left[\mathrm{e}^{(0.056)}-1\right]\right)$ compared to residence in Kyoga plains. On the other hand, keeping other things equal, a female headed household is $15 \%$ less likely to depend on wetlands for food security.

\section{Discussion}

\section{People's experiences of food insecurity}

The poor socio-economic status of the households, particularly the low incomes, suggests susceptibility to food insecurity. As noted by Kydd et al. [35] and DFID [36], food insecurity is closely related to poverty and an inability to purchase food, especially in the agriculture-based rural areas. Uganda is frequently considered food secure, especially when compared to the other eastern African countries, but this study reveals high incidences of food insecurity. While there is increasing recognition that situations of food insecurity are brought about by a complex and dynamic set of causes [37], food insecurity in Uganda is increasingly reported to coincide with harsh weather conditions especially during the prolonged droughts and periods of heavy rain. Changes in the patterns of extreme weather events such as floods and droughts affect food production as well as stability of and access to food supplies. This is a general trend in crop production, where huge losses due to crop failures, arising from droughts and flooding, are being experienced more frequently than ever before in Africa, causing famines and economic hardships [38]. Local people's linkage of food insecurity to climate change is supported by, among others, Vlassenroot et al. [38], who assert that food insecurity is a direct consequence of food shortages caused by climatic variables or demographic pressures. Perhaps this could be the reason why local people use wetlands as safety nets during the drought since wetlands are able to store more water and moisture during the dry periods. Taking a single meal a day seems to be a commonly agreed indicator of food insecurity, but also adapted as a coping strategy across sub-Saharan Africa [39].

Prevalence of food insecurity is significantly lower among households with older and better educated household heads because ability to access assets needed to secure livelihoods increase with seniority and, as noted by Muchapodwa [40], education makes it easier for households to comprehend negative externalities and be able to generate cash for buying food. Households located in Lake Victoria Crescent and south-western farmlands are less susceptible to food insecurity because both zones have better access to perennial crops, particularly bananas. The south-western farmlands are the main areas for banana production in Uganda and have a vibrant livestock-based economy that can complement crop production for both cash and subsistence

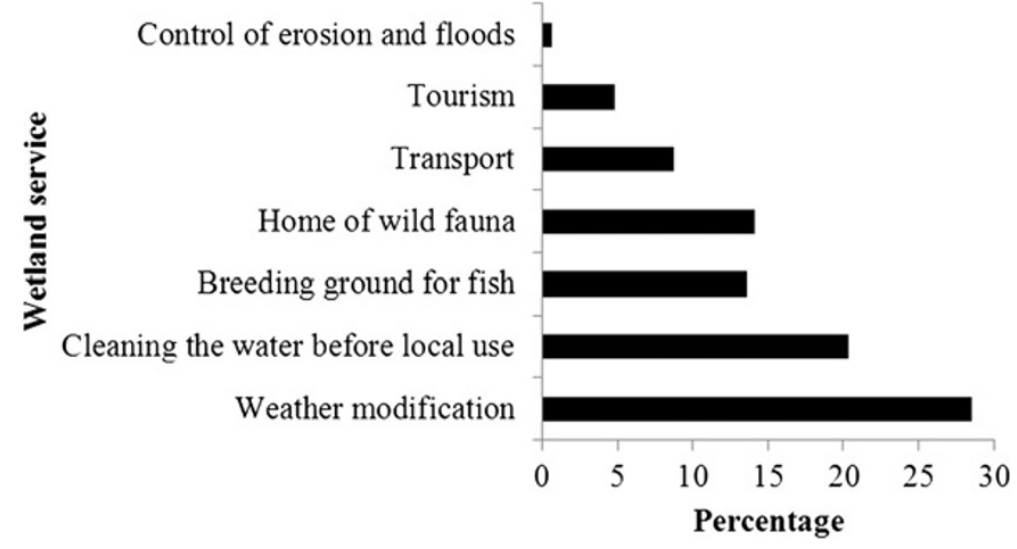

Figure 6 Wetland services indirectly contributing to household food security in Uganda. 
Table 2 Factors influencing dependence on wetlands for food security among households adjacent to wetlands in Uganda

\begin{tabular}{|c|c|c|c|c|c|}
\hline Dependent variable* & Units & Coef. & Std. Err. & z & $P>z$ \\
\hline \multicolumn{6}{|l|}{ Household characteristics } \\
\hline Age & Years & 0.003 & 0.001 & 2.12 & 0.034 \\
\hline Household female headed & $0 / 1$ & -0.150 & 0.080 & -1.86 & 0.062 \\
\hline Education level & Years & -0.008 & 0.020 & -0.40 & 0.693 \\
\hline Household size & Number & -0.001 & 0.003 & -0.17 & 0.868 \\
\hline Length of stay in the area & Years & -0.001 & 0.001 & -0.66 & 0.512 \\
\hline Distance to wetland & $\mathrm{km}$ & 0.003 & 0.030 & 0.09 & 0.931 \\
\hline Location in South western farmlands & $0 / 1$ & -0.041 & 0.039 & -1.05 & 0.295 \\
\hline Location in Lake Victoria Crescent & $0 / 1$ & 0.056 & 0.031 & 1.83 & 0.067 \\
\hline Primary occupation is farming & $0 / 1$ & -0.033 & 0.038 & -0.85 & 0.394 \\
\hline Primary occupation is formal employment & $0 / 1$ & -0.208 & 0.188 & -1.11 & 0.268 \\
\hline Household suffers food insecurity & $0 / 1$ & 0.087 & 0.062 & 1.39 & 0.165 \\
\hline Number of observations & & & & & 236 \\
\hline Log likelihood & & & & & -41.79 \\
\hline $\operatorname{LR} x^{2}(11)$ & & & & & 22.67 \\
\hline Prob $>x^{2}$ & & & & & 0.019 \\
\hline Pseudo R2 & & & & & 0.213 \\
\hline
\end{tabular}

*Dependent variable is a binary variable depicting whether or not a household depends on wetlands for food security ( 1 = Household is dependent;

$0=$ Otherwise)

incomes. On the other hand, the Lake Victoria Crescent is adjacent to Kampala, Uganda's capital city and the industrial town of Jinja, and the local people thus have better access to alternative sources of cash income that can then be used to purchase food.

On the other hand, the prevalence of food insecurity is higher among female headed households, possibly because they frequently have less access to adult labor [41], and may lack the means to seek employment away from their families [42]. Generally, female headed households are more vulnerable to food insecurity because of their tighter time schedules and income constraints [43-45].

Larger households were more food insecure because these typically have a greater dependence and consumer burden [46]. This then becomes a problem in areas where production is already low, typical of most rural areas in Uganda.

Increased susceptibility to food insecurity for a household that utilizes wetlands for food security is a relationship that can be interpreted in two ways: i) households collected wetland resources were susceptible to food insecurity because of their dependence on wetlands; or ii) households collected wetland resources because they were food insecure. The latter seems to be more likely as food insecure households turn to collecting wetland resources as safety net or gap-filler. This is typical in sub-Saharan countries where households with limited livelihood options utilize common pool resources, including wetlands
$[11,47]$ and forest resources $[41,48]$ as a means of meeting household food and income.

\section{Contribution of wetlands to household food security}

A vast majority of people were directly dependent on wetland resources for food security similar to previous studies and reports in Uganda, particularly among resource poor and larger households $[28,49,50]$, for whom wetlands are then a major source of cash and subsistence income that supplements other sources.

The practice of growing crops in wetlands may be the preponderance of rural households with limited access to other productive assets (such as land) or sources of income. This is evident among the households studied with average land size of 3.8 acres and household size of eight persons. Studies conducted elsewhere in Uganda indicated that in situations of inadequate land, people resort to natural resources including wetlands as alternative sources of land for crop and livestock farming [28,51,52]. Studies carried out elsewhere in Africa also report rural dependence on wetlands for food production [20]. This is mainly because wetlands have some relatively higher levels of water/ moisture, particularly in the dry season, compared to the surrounding catchment areas. In some cases, wetlands have some relatively high levels of fertility due to the silt accumulated by run-off from surrounding catchments. Given the current unpredictable rainfall, it is inevitable that local communities will largely rely on wetlands for 
food security, especially during prolonged dry periods, a situation also noted by Grimble et al. [53], which justifies the need for research in more technological and social innovations to improve sustainable use of wetlands for improved food security.

Wetlands take a more pronounced role in Kyoga plains where rice is grown as a main source of both food and cash. Similar levels of reliance on rice growing were reported by Karanja et al. [49]. In Rwanda's wetlands of Cyabayaga, rice was also reported as the largest contributor to household income providing on average $\$ 1,045$ (approx. UGX 2,612,500) per household per season [14]. Wetlands in the two districts are also one of the most productive and resourceful areas, which provide food from aquatic ecosystems such as fish for the local people.

The local people recognize wetlands to provide a variety of services, which reinforces local valuation of wetlands and, by extension, willingness to participate in wetland conservation.

\section{Factors influencing dependence on wetlands for food production}

Wetland utilization for food security is higher among households with older heads possibly because these have better access to social networks through which to access common pool resources including wetlands. On the other hand, residence in the Lake Victoria Crescent is associated with higher dependence on wetlands because the zone has many urban poor households that at best have very limited access to land and thus end up encroaching on wetlands which are still regarded as common pool resources. Lower utilization of wetlands among households headed by females is possibly because of lower access to social networks crucial for access to such common pool resources.

\section{Conclusions and recommendation}

Over $80 \%$ of all households had experienced food insecurity, characterized by low harvest and households having a single meal in a day, and the main causes being unpredictable weather and inadequate arable land. The prevalence of food insecurity is higher in large sized, female headed and uneducated households. Land shortage, household size coupled with limited off-farm opportunities to generate cash for purchase of food drive local people into utilization of wetland resources as an alternative source of household food.

Wetlands are the basis of food security, directly providing resources for consumption, indirectly supporting crop and livestock production, materials that are sold for purchasing food in emergency situations and services that support food production. The most interesting feature of wetlands is that they provide conditions that enable a wider range of crops than dry lands, and therefore provide ready food supplies to wetland adjacent communities during unfavorable conditions that are otherwise unavailable for the traditional crops grown in the uplands. Beyond subsistence agriculture, wetlands are increasingly offering products for additional income through cultivation of locally marketable crops such as rice, sugar cane and vegetables. These products are sold and income is used to buy household food supplements.

With increasing population around the wetlands, coupled with land shortage and weather variations, the poor people, especially in rural areas, will continue to generally rely on wetland ecosystem services directly for subsistence and income generating activities for sustaining their livelihoods unless alternative livelihood options are provided. With rain-fed agriculture being the primary food production option for people living adjacent to wetlands in Uganda, there are risks of many people being vulnerable, and who could see their food security seriously limited. Thus, there is a need to design food production technologies and alternative income generating activities that ensure sustainable use of wetland resources for food security.

\section{Abbreviations \\ FAO: Food and Agriculture Organization of the United Nations; \\ MDG: Millennium Development Goal; NDP: National Development Plan; NEMA: National Management Authority; WFP: World Food Programme.}

\section{Competing interests}

The authors declare that they have no competing interests.

\section{Authors' contribution}

NT designed the study, collected data and coordinated the write up. WK participated in collection and analysis of data and write up. MT participated in literature search and write up. DMT participated in data analysis and write up. All authors read and approved the manuscript.

\section{Authors' information}

NT is an Associate Professor in the Department of Extension and Innovation Studies, College of Agricultural and Environmental Sciences, Makerere University.

WK is a part time lecturer in the School of Forestry, Environmental and Geographical Sciences, Makerere University and a Consultant on Natural Resources Management.

MT is an Ecologist and a Professor in the Department of Forestry, Biodiversity and Tourism, School of Forestry, Environmental and Geographical Sciences, College of Agriculture and Environmental Sciences, Makerere University. DMT is a Research Fellow at the Norwegian University of Life Sciences and lectures at the Department of Environmental Management, School of Forestry, Environmental and Geographical Sciences, Makerere University (Uganda).

\section{Acknowledgements}

The authors would like to thank the International Development Research Centre (IDRC) for funding this study in partnership with Makerere University and Wetlands Management Department, Ministry of Water and Environment and National Agricultural Research Organisation (NARO). We would like to thank Fred Yikii, Teddy Tindamanyire and Vincent Barugahare for participation in data collection and preparation of the draft report. We would also like to thank Lucy lyango, Gilbert Ituka, Euzobia Arinaitwe and Asiimwe Joseph for participation in data collection. We would like to thank communities around wetlands in Wakiso, Pallisa, Kibuku, Isingiro and Mbarara Districts for their cooperation during data collection.

\section{Author details}

${ }^{1}$ Department of Extension and Innovation Studies, College of Agricultural and Environmental Sciences, Makerere University, P.O. Box 7062, Kampala, 
Uganda. ${ }^{2}$ Department of Forestry, Biodiversity and Tourism, College of Agricultural and Environmental Sciences, Makerere University, P.O. Box 7062, Kampala, Uganda. ${ }^{3}$ Department of Environmental Management, School of Forestry, Environment and Geographical Sciences, Makerere University, P.O. Box 7062, Kampala, Uganda. ${ }^{4}$ Department of International Environment and Development Studies (Noragric), Norwegian University of Life Sciences (UMB), P.O. Box 1432, Aas, Norway.

Received: 10 September 2012 Accepted: 19 February 2013 Published: 25 March 2013

\section{References}

1. Lisa LC, Alderman H, Aduayom D: Food Insecurity in Sub-Saharan Africa: New Estimates from Household Expenditure Surveys. Research Report, 146. Volume Research Report. Washington, DC: 146, International Food Policy Research Institute (IFPRI); 2006

2. Food and Agriculture Organization of the United Nations: The State of Food Insecurity in the World. Rome: FAO; 2001

3. Food and Agriculture Organization of the United Nations: The State of Food Insecurity in the World. Rome: FAO; 2009

4. Cooper PJM, Dimes J, Rao K, Shapiro B, Twomlow S: Coping better with current climatic variability in the rain-fed farming systems of SubSaharan Africa: An essential first step in adapting to future climate change? Agric Ecosystem Environ 2008, 126:24-35.

5. Jones PG, Thornton PK: Croppers to livestock keepers: Livelihood transitions to 2050 in Africa due to climate change. Environ Sc. Policy 2009, 12:427-437.

6. Food and Agriculture Organization of the United Nations: Food Security and Agricultural Development in Sub-Saharan Africa: Building a Case for More Public Support. Rome: FAO; 2006.

7. Ellis-Jones J, Mudhara M: Factors affecting the adoption of soil and water conservation technologies in semi-arid Zimbabwe. In Soil and Water Conservation for Small Farmers in Semi Arid Zimbabwe, Transfers between Research and Extension. Proceedings of Technical Workshop, 3-7 April 1995, Masvingo Zimbabwe. Edited by Twomlow S, Ellis-Jones J, Hagmann J, Loos H. Masvingo: Silsoe Research Institute Report OD/95/16; 1995.

8. Mutambikwa A, Muzenda S, Chivinge O, Ellis-Jones J, Riches C, Twomlow S: Participatory Evaluation of Vlei Utilization and Weed Problems in Communal, Resettlement and Small Scale Commercial Farming Systems of Masvingo and Gutu districts; Report IDG/00/8. Silsoe Bedford: Silsoe Research Institute; 2000.

9. Dixon AB: The hydrological impacts and sustainability of wetland drainage cultivation in Illubabor, Ethiopia. Land Degr Develop 2002, 13:17-31.

10. Dixon $A B$, Wood AP: Wetland cultivation and hydrological management in eastern Africa: matching community and hydrological needs through sustainable wetland use. Nat Resources Forum 2003, 27:117-129.

11. Halima KH, Munishi KTP: Contribution of wetlands to household income and food security in the Nyumba Ya Mungu wetland system, northern Tanzania. Tanzania J Forestry Nat Conserv 2009, 79(2):99-108.

12. Adams WM: Indigenous use of wetlands and sustainable development in West Africa. Geogr J 1993, 159:209-218.

13. Abbot P, Afework H: Report on the PRA Training Workshop for Sustainable Wetland Management. EWRP, Metu. Working Paper; 1997.

14. Nabahungu NL, Visser SM: Contribution of wetland agriculture to farmers' livelihood in Rwanda. Ecol Econ 2011, 7:4-12.

15. Maclean I, Tinch R, Hassall M, Boar R: Social and Economic Use of Wetland Resources: A Case Study from Lake Bunyonyi, Uganda. Working Paper ECM 03-09. Norwich, United Kingdom: University of East Anglia, Centre for Social and Economic Research on the Global Environment; 2003.

16. Schuyt KD: Economic consequences of wetland degradation for local populations in Africa. Ecol Econ 2005, 53:177-190.

17. Turpie J, Barnes J, Arntzen J, Nherera B, Lange GM, Buzwani B: Economic Value of the Okavango Delta, Botswana and Implications for Management Okavango Delta Management Plan; 2006.

18. Shackleton CM, Shackleton S: Household wealth status and natural resource use in the Kat River valley, South Africa. Ecol Econ 2006, 57:306-317.

19. Masiyandima M, McCartney MP, Van Koppen B: Wetland Contributions to Livelihoods in Zambia FAO Netherlands Partnership Program: Sustainable Development and Management of Wetlands Rome: FAO; 2004:50.

20. McCartney MP, Van Koppen B: Wetland Contributions to Livelihoods in United Republic of Tanzania. FAO Netherlands Partnership Program: Sustainable Development and Management of Wetlands. Rome: FAO; 2004:42.
21. Mwakubo SM, Obare GA: Vulnerability, livelihood assets and institutional dynamics in the management of wetlands in Lake Victoria watershed basin. Wetl Ecol Manag 2009, 17:613-626.

22. The Republic of Uganda: National Development Plan for Uganda. 2010/112014/15. Kampala; 2010.

23. Famine Early Warning Systems Network: Uganda Food Security Outlook. Kampala: FEWS-Net; 2010.

24. United Nations World Food Programme: Comprehensive Food Security and Vulnerability Analysis (CFSVA) in Uganda. UNWFP; 2009.

25. International Food Policy Research Centre: IFPRI Strategy Towards Food and Nutrition Security. Washington, DC: International Food Institute; 2003.

26. International Fund for Agricultural Development: Rural Poverty Report. London: Oxford University Press; 2001.

27. Nyakana JB: Sustainable wetland resource utilization of Sango Bay through eco-tourism development. Afr J Environ Sci Technol 2008, 2:326-335.

28. Wetlands Management Department: Ministry of Water and Environment, Uganda Bureau of Statistics, International Livestock Research Institute, World Resources Institute: Mapping a Better Future: How Spatial Analysis can Benefit Wetlands and Reduce Poverty in Uganda. Washington DC and Kampala: World Resources Institute; 2009.

29. Ministry of Water: Lands and Environment: National Wetlands Programme End of Phase III report. Kampala: Wetlands Inspection Division; 1999.

30. Young $\mathrm{H}$, Jaspars $\mathrm{S}$, Brown R, Frize J, Khogali H: Food-Security Assessments in Emergencies: A Livelihoods Approach. London: Humanitarian Practice Network Paper No.36, Overseas Development Institute; 2001.

31. Kennedy E: Qualitative measures of food insecurity and hunger. In Measurement and Assessment of Food Deprivation and Under Nutrition. Rome: FAO; 2003:165-180.

32. Agresti A: Categorical Data Analysis. 2nd edition. Hoboken, New Jersey: Wiley Series in Probability and Statistics; 2002.

33. Bartus T: Estimation of marginal effects using Margeff. Stata J 2005, 5:309-329.

34. Wooldridge JM: Introductory Econometrics: A Modern Approach. UK: South-Western; 2009

35. Kydd J, Dorward A, Morrison J, Cadisch G: Agricultural Development and Pro-Poor Economic Growth in Sub-Saharan Africa: Potential and Policy. ADU Working Paper 02/04. Imperial College: Wye; 2002.

36. Department for International Development: Agriculture, Growth and Poverty Reduction. London: DFID; 2004.

37. Devereux S: Famine in the Twentieth Century. IDS Working Paper No. 105. Brighton: Institute of Development Studies; 2000.

38. Mwendera E: Situation Analysis for Water and Wetlands Sector in Eastern and Southern Africa: Draft Report, International Union for Conservation of Nature (IUCN). Nairobi: Eastern and Southern Africa Regional Office (ESARO); 2010.

39. Vlassenroot K, Salomé Ntububa S, Raeymaekers T: Food Security Responses to the Protracted Crisis Context of the Democratic Republic of the Congo. 2006.

40. Muchapodwa E: The Economics of Community-Based Wildlife Conservation in Zimbabwe. PhD Thesis, Department of Economics. Harare: Göteborg University, Sweden and University of Zimbabwe; 2003.

41. Vedeld P, Angelsen A, Sjaastad E, Kobugabe BG: Counting on the Environment: Forest Incomes and the Rural Poor, Environment Economics Series Paper 98. Washington DC: World Bank; 2004.

42. Shackleton C, Shackleton S: The importance of non-timber forest products in rural livelihood security and as safety nets: a review of evidence from South Africa. South African J Sci 2004, 100:658-664.

43. Caldwell R, Seroussi M, Hagens C, Huddle J, Mbizule C, Uny K: Malawi Baseline Survey: Report Findings Prepared for C-SAFE Tueson. Ariz, USA: Tango International; 2003

44. Food and Agriculture Organisation of United Nations: Women and Food Security. Rome: FAO; 1996.

45. Gladwin C, Thomson A: Food or Cash Crops? Which is the Key to Food Security: Prepared for the University of Florida's Gender and Soil Fertility in Africa. 2004.

46. Godoy R, O'neill K, Groff S, Kostishack P, Cubas A, Demmer J, McSweeney K, Overman J, Wilkie D, Brokaw N: Household determinants of deforestation by Amerindians in Honduras. World Dev 1997, 25:977-987.

47. MEA (Millennium Ecosystem Assessment): Ecosystems and Human Well-Being: Wetlands and Water, Synthesis. Washington, DC, USA: World Resources Institute; 2005

48. Tumusiime DM, Vedeld P, Gombya-Ssembajjwe W: Breaking the law? Illegal livelihoods from a protected area in Uganda. Forest Policy Econ 2011, 13:273-283. 
49. Karanja F, Emerton L, Mafumbo J, Kakuru W: Assessment of the Economic Value of Pallisa District Wetlands. Kampala, Uganda: Biodiversity Economics Programme for Eastern Africa, IUCN-The World Conservation Union and Uganda National Wetlands Programme; 2001.

50. National Environment Management Authority (NEMA): State of the Environmental Report for Uganda, 2008. Kampala: NEMA; 2008.

51. National Environment Management Authority (NEMA): Environmental Sensitivity Atlas for the Albert Graben. Secondth edition. Kampala: NEMA; 2010

52. Rwanda Environmental Management Authority: Rwanda State of Environment and Outlook: Our Environment for Economic Development. Kigali: REMA; 2009.

53. Grimble R, Cardoso C, Omar-Chowdhury S: Poor People and the Environment: Issues and Linkages. 16th edition. Greenwich: Natural Resources Institute; 2002.

doi:10.1186/2048-7010-2-5

Cite this article as: Turyahabwe et al: Contribution of wetland resources to household food security in Uganda. Agriculture \& Food Security 2013 2:5.

\section{Submit your next manuscript to BioMed Central and take full advantage of:}

- Convenient online submission

- Thorough peer review

- No space constraints or color figure charges

- Immediate publication on acceptance

- Inclusion in PubMed, CAS, Scopus and Google Scholar

- Research which is freely available for redistribution 